\title{
DIVISIVE REORGANIZATIONS UNDER THE INTERNAL REVENUE CODE OF 1954
}

Distributions of stock and securities of a controlled corporation pursuant to a corporate division may be received by stockholders without tax incidence if the distributing and controlled corporations comply with the statutory requirements of section 355 of the Internal Revenue Code of 1954 and the regulatory tests of the Internal Revenue Service. Divisions which give rise to such distributions fall within three categories: spin-offs, split-offs and splitups. A spin-off is effected when corporation $A$, distributing corporation, organizes corporation $B$, controlled corporation, transfers part of its assets to $B$ in exchange for all of $B$ 's stock and distributes $B$ 's stock to its own shareholders, or when $A$ merely distributes to its shareholders stock of a controlled subsidiary. A split-off differs only in that stockholders of the distributing corporation surrender part of their stock in exchange for stock of the controlled corporation. In a split-up, $A$ transfers part of its assets to $B$, the remainder to $C$-both controlled corporations-receives all the stock in $B$ and $C$ and, in complete liquidation, distributes $B$ and $C$ stock in exchange for its own. The immediate economic consequences to $A$ 's stockholders of all three transactions are identical. ${ }^{1}$ But until the 1954 Code, divergent tax consequences attended each method.

The 1939 Code incorporated the practice of the Internal Revenue Service which was to allow tax-free split-up distributions and to tax spin-off distributions as dividend income. In the case of split-ups, $A$ 's transfer of assets to $B$ and $C$ in exchange for stock qualified as a reorganization under section 112 (g) (1) (D).2 Thus $A$ recognized neither gain nor loss on this exchange by

1. Distributions of the controlled corporation's stock occasion no change in each stockholder's proportionate ownership of the reshuffled corporate assets irrespective of whether stock in the distributing corporation has been exchanged. For example, corporation $A$, owned equally by two stockholders, is composed of two active businesses-each valued at $\$ 1,000$. Subsequent to a spin-off of one business, each stockholder's share in the new corporation would represent $\$ 500$ of assets, and the shares retained in the distributing corporation would be worth the same amount. If, instead, a split-off had been effected the two stockholders would have exchanged some of their shares in the distributing corporation for all the stock of the controlled corporation. In this case each stockholder would also own $50 \%$ or $\$ 500$ of both corporations. Execution of a split-up would have resulted in the shareholders' exchange of all of the distributing corporation's stock for that of the controlled corporations. And the stock received in the two controlled corporations would also represent $50 \%$ ownership in each. 3 MERTENs, FedERAL InCOME TAXation $\$ 20.101$, at $428-29$ (rev. ed. 1957) ; Peterson, Subchapter C of the Internal Revenue Code of 1954 III. Corporate Organizations and Reorganizations, 30 Notre Dame LAw. 617, 642 (1955).

2. Int. Rev. Code of $1939, \S 112(\mathrm{~g})(1)(\mathrm{D})$, as amended, 58 STAT. 43 (1944), quoted at note 11 infra. 
virtue of section 112 (b) (4)..$^{3}$ Similarly, the distribution to $A$ 's shareholders of $B$ and $C$ stock in exchange for $A$ stock was tax-free under section $112(\mathrm{~b})(3) .^{4}$ On the other hand, spin-offs, which qualified as nontaxable reorganizations at the corporate level, ${ }^{5}$ gave rise to taxable distributions at the stockholder level since the requirement in section 112 (b) (3) of an exchange of stock by $A$ 's stockholders could not be met. ${ }^{6}$ Split-offs, though technically observing the 1939 provisions in the same manner as split-ups, were considered by the Internal Revenue Service to be functionally equivalent to spin-offs and, consequently, were treated as taxable distributions to the recipient stockholders. ${ }^{7}$

Section 112(b) (11), added to the Code in 1951, permitted nontaxable spinoff distributions within certain limits. This section expressly provided that no gain to distributees should be recognized unless it appeared that the corporate parties to the spin-off were not intended to continue the active conduct of a trade or business or that the controlled corporation was used principally as a device to distribute earnings and profits. 8 These rules prototyped the more elaborate framework of section 355 of the 1954 Code, but unnecessary pro-

3. Int. Rev. Code of $1939, \S 112$ (b) (4), 53 STat. 37 :

"No gain or loss shall be recognized if a corporation a party to a reorganization exchanges property, in pursuance of the plan of reorganization, solely for stock or securities in another corporation a party to the reorganization."

4. Id. $\S 112(b)(3), 53$ Stat. 37 :

"No gain or loss shall be recognized if stock or securities in a corporation a party to a reorganization are, in pursuance of the plan of reorganization, exchanged solely for stock or securities in such corporation or in another corporation a party to the reorganization."

Heatley Green, 1 CCH Tax Ct. Mem. 297 (1942) ; S. ReP. No. 398, 68th Cong., 1st Sess. 14-15 (1924).

5. See note 2 supra and accompanying text.

6. Int. Rev. Code of $1939, \S 112$ (b) (3), 53 Stat. 37, quoted at note 4 supra.

7. Bittker, Federal Income Estate and Gift Taxation 546 (1955); Peterson, supra note 1 , at 643 .

The Treasury's position in disqualifying split-offs despite the statutory exchange was finally rejected by the tax court in Chester E. Spangler, 18 T.C. 976 (1952). The Commissioner subsequently conceded the point. Rev. Rul. 289, 1953-2 CuMr. BuLl. 37. See Rena B. Farr, 24 T.C. 350 (1955) ; Thomas L. Williams, 12 CCH Tax Ct. Mem. 186 (1953).

8. Int. Rev. Code of 1939, §112(b) (11), added by 65 Stat. 493 (1951) :

"Distribution of Stock not in Liquidation. If there is distributed, in pursuance of a plan of reorganization, to a shareholder of a corporation which is a party to the reorganization, stock (other than preferred stock) in another corporation which is a party to the reorganization, without the surrender by such shareholder of stock, no gain to the distributee from the receipt of such stock shall be recognized unless it appears that (A) any corporation which is a party to such reorganization was not intended to continue the active conduct of a trade or business after such reorganization, or (B) the corporation whose stock is distributed was used principally as a device for the distribution of earnings and profits to the shareholders of any corporation a party to the reorganization." 
scriptions of disproportionate ${ }^{9}$ and preferred stock distributions ${ }^{10}$ and the requirement that a holding company be created to accomplish the spin-off of a controlled subsidiary were eliminated by the new section. ${ }^{11}$

9. INT. REv. CODE oF 1954, $\$ 355$ (a) (2), provides that nonrecognition treatment will be available "(A) whether or not the distribution is pro rata with respect to all of the shareholders of the distributing corporation ...." Under U.S. Treas. Reg. \$ 1.355-3(a) (1955), however, "section 355 does not apply . . . if the substance of the transaction is merely an exchange between shareholders or security holders of stock or securities in one corporation for stock or securities in another corporation. For example, if two individuals, $C$ and $D$, each own directly fifty percent of the stock of Corporation $M$ and fifty percent of the stock of Corporation N, section 355 would not apply to a transaction in which $C$ and $D$ transfer all of their stock in Corporation $M$ and Corporation $\mathrm{N}$ to a new corporation, $\mathrm{P}$, for all of the stock of Corporation $\mathrm{P}$, and Corporation $\mathrm{P}$ then distributes the stock of Corporation M to C and the stock of Corporation N to D." Cf. Rev. Rul. 55-103, 1955-1 Cuar. Bull. 31.

Disproportionate distributions which substantially favor one stockholder may be classified as gifts or compensation, and be taxed, respectively, under $\$ 2501$ or $\$ 61$ (a) (1). INT. REv. CODE of 1954, § 356(f) ; S. Rep. No. 1622, 83d Cong., 2d Sess. 50 (1954) ; Friedman, Divisive Corporate Reorganizations Under the 1954 Code, 10 TAx L. REv. 487, 504 (1955).

10. INT. REV. CODE OF 1954, § 355 (a) (1) (A) (i), permits tax-free distributions of "stock" to shareholders. Defining this term, U.S. Treas. Reg. $\$ 1.355-3$ (b) (1955) states, "stock of the controlled corporation which is distributed may consist of either common or preferred stock."

The principal reason for removing $\$ 112(\mathrm{~b})$ (11)'s prohibition, see note $\$$ supra, is the availability of $\$ 306$ in the new Code to prevent preferred stock bail-outs. Transactions by which nontaxable preferred stock dividends were declared upon common stock and thereafter sold at capital gains rates constituted a notorious avenue of tax avoidance under the 1939 Code. See C. P. Chamberlin, 18 T.C. 164 (1952), rev'd, 207 F.2d 462 (6th Cir. 1953), cert. denied, 347 U.S. 918 (1954), wherein the tax court held that a taxable dividend resulted, but was reversed on review. Section 112 (b) (11) therefore properly foreclosed the possibility of using tax-free spin-off distributions as an instrument of this device. But with the advent of $\S 306$, a prohibition of preferred stock distributions in pursuance of divisive reorganizations became unnecessary. Under $\$ 306(\mathrm{c})(1)(B)$, preferred stock received in a § 355 distribution will generally be classified as "Section 306 stock." Alexander \& Landis, Bail-outs and the Internal Revemue Code of 1954, 65 YaLE L.J. 909 (1956). And upon the sale of such stock, $\S 306$ (a) (1) (A) provides "the amount realized shall be treated as gain from the sale of property which is not a capital asset." For the broad effects of $\S 306$, see Alexander \& Landis, supra. But see Dean, Spin-offs: General Rules; Requirements as to Active Bussiness; Some Practical Considerations (Section 355), N.Y.U. 15TE INST. oN FED. TAX. 571, 574 n.14 (1957) (suggesting that a substantially disproportionate distribution of preferred stock pursuant to a corporate division should avoid the $\$ 306$ stigma).

Another important change effected by the 1954 Code is that securities may be received tax-free in corporate divisions which otherwise qualify under $\S 355$. Unlike distributions of stock, however, securities can be received without tax incidence only if stock or security holders surrender other securities in exchange. Section 355(a) (3) (B). Similarly, security holders, must surrender their securities in order to obtain a nontaxable distribution of stock or securities or both. Section 355 (a) (1) (A) (ii). If the principal amount of securities received exceeds the principal amount of securities surrendered, or if securities are received without surrender of any securities, or if any stock received was acquired with tax consequence by the distributing corporation within five years prior to the distribution, then the 
Section 355 of the 1954 Code, the axis of the present statutory pattern applicable to divisive reorganizations, accords uniform treatment to all corporate divisions. ${ }^{12}$ The importance of section 355 is emphasized by definitional changes in the 1954 counterpart of section $112(\mathrm{~g})(1)(\mathrm{D})$, section 368(a) (1) (D), which prevent corporations from using section 368 as an escape-hatch from section 355's requirements. Corporate exchanges of assets for stock do not qualify as reorganizations under section 368 (a)(1)(D) unless stock or securities of the controlled corporation are distributed in a transaction which

entire transaction will be governed by the "boot" provisions of $\S 356$. Sections 355 (a) (3), (4).

Section 356, which treats divisive reorganization distributions of nonqualifying property, draws a distinction between splits and spins. Under $\$ 356(\mathrm{a})(1)$ and $\$ 356(\mathrm{~b})$, if the property distributed in corporate divisions consists not only of property which may be received tax-free under $\$ 355$, but also of nonpermissible "boot"-the excess of the principal amount of securities received over the principal amount of securities surrendered, the securities received when none are surrendered, and the stock received which was acquired with tax consequence by the distributing corporation-gain is recognized in an amount limited to the sum of the money and the fair market value of the other property constituting such "boot." In exchanges which have the effect of distributing dividends, the gain recognized under $\$ 356$ (a) (1) is treated as a dividend to the extent of the distributee's ratable share of corporate earnings and profits accumulated after 1913. Section 356 (a) (2). Insofar as securities may be equated with cash, distributions of excess securities will probably give rise to dividend income. The remainder of gain is subject to capital gains taxation under $\$ 356$ (a) (2). By virtue of $\$ 356(\mathrm{~b})$, however, the entire amount of "boot" received in spin-off distributions is treated as dividend income under the provisions of $\$ 301$, whether or not such distributions have the effect of a dividend. Since the distributee's proportionate interest in the corporation remains the same whether or not he surrenders part of his stock, note 1 supra, this differential treatment seems unreasonable. The question has been raised, but as yet remains unanswered, if a token surrender of stock in what is substantially a spin-off distribution would evoke the premium $\$ 356$ affords exchange transactions. Friedman, supra note 9 , at 508 .

11. Int. Rev. Code of 1939, $\S 112$ (b) (11), added by 65 STAT. 493 (1951), required that a corporate division be "in pursuance of a plan of reorganization" and that the controlled corporation be "a party to the reorganization." The reorganization contemplated by this language was prescribed in $\S 112(\mathrm{~g})(1)(D)$ :

"A transfer by a corporation of all or a part of its assets to another corporation if immediately after the transfer the transferor or its shareholders or both are in control of the corporation to which the assets are transferred ...."

Accordingly, an existing subsidiary could only be spun-off tax-free when its stock was first transferred to a newly created holding company, and the stock of the latter corporation was distributed to shareholders. That this curious result was actually intended by Congress, "whether or not [the subsidiary was] wholly or even majority owned," is demonstrated by the committee report. S. REP. No. 781, $82 d$ Cong., 1st Sess., pt. 1, 57-58 (1951). Section $355(a)(2)(C)$, however, permits nontaxable divisions "whether or not the distribution is in pursuance of a plan of reorganization (within the meaning of section 368(a) (1) (D))."

12. INT. REv. CODE OF 1954, $\S 355$ (a) (2), provides: "[P]aragraph (1) shall be applied without regard to the following:... (B) whether or not the shareholder surrenders stock in the distributing corporation ...." 
qualifies under section $355 . .^{13}$ However, corporate divisions not qualifying under sections 355 or 368 may receive tax-free treatment at the corporate level under section 351 if the distributing corporation obtains, in exchange for assets transferred, control of the corporation whose stock is to be distributed. ${ }^{14}$ Nevertheless, spin-off distributions and split-off and split-up exchanges will be taxable at the stockholder level if they fail to meet the requirements of section $355 .{ }^{10}$ Such transactions are nontaxable only if the corporate parties conform to re-

13. Id. $\S 368$ (a) (1), provides:

"[T] he term 'reorganization' means ... (D) a transfer by a corporation of all or part of its assets to another corporation ... but only if, in pursuance of the plan, stock or securities of the corporation to which the assets are transferred are distributed in a transaction which qualifies under section 354,355 , or $356 \ldots$. ."

For distributions to be nontaxable under $\$ 354(\mathrm{~b})$ the parent must: (1) transfer substantially all of its assets to only one transferee subsidiary, and (2) disperse all its properties, including the stock and securities of the subsidiary, to its shareholders or security holders. Thus $\$ 354$ is designed to control only combinative (D) reorganizations and is obviously inapplicable to corporate divisions. Dean, supra note 10 , at 575 . Similarly, $\S 356$ does not come into play unless the distribution would have qualified under $\$ 354$ or $\$ 355$ but for the dispersement of "other property or money." Thus all divisive reorganizations must qualify under $\S 355$ to be nontaxable at the shareholder level.

14. INT. Rev. CODE of $1954, \S 351$ (a), relevantly provides:

"No gain or loss shall be recognized if property is transferred to a corporation by one or more persons solely in exchange for stock or securities in such corporation and immediately after the exchange such person or persons are in control (as defined in section 368(c)) of the corporation."

Under $\$ 351(b)$, property received other than stock or securities of the transferor corporation constitutes taxable gain to the transferee.

15. The tax consequences accompanying distributions pursuant to nonqualifying divisions may be dependent upon the form of a separation. Distributions of stock in a nonqualifying spin-off would be taxed under $\$ 301$ as dividend income to the extent of earnings and profits. Knapp \& Repetti, Problems in Distribution of Stock and Securities of a Controlled Corporation, N.Y.U. 14rH INST. on FED. TAX. 787, 805-06 (1956). Nonqualifying split-off distributions on the other hand, literally satisfy the redemption of stock definition of $\S 317$ (b). Thus, such exchanges might be accorded capital gains treatment as "redemptions not equivalent to dividends," $\$ 302$ (b) (1), or as "substantially disproportionate redemption [s] of stock," $\$ 302(\mathrm{~b})(2)$. They might also receive capital gains treatment as distributions in partial liquidation, as defined by $\$ 346$ (a) (1) or (2) to which $\$ 301$ would be inapplicable under the terms of $\S 331$ (b). See Giles E. Bullock, 26 T.C. 276, 292 (1956) (split-off taxed as partial liquidation under the 1939 Code). Conceivably, distribution of stock pursuant to nonqualifying split-ups might also receive capital gains treatment as distributions in complete liquidation under $\$ 331$ (a).

Another approach would be to treat distributions involved in all nonqualifying divisions uniformly as dividend income. The argument would run that the restrictions of $\S 355$ were designed to prevent divisive reorganizations from converting dividend income into capital gain. Hence, all nonqualifying divisions would be regarded as distributions of earnings to be governed by $\S 301$. MToreover, split-offs and split-ups produce the same economic effects as spin-offs, see note 1. supra; and since a nonqualifying spin-off would be taxed as a dividend under $\$ 301$, nonqualifying splits might be treated identically. Under this approach, splits which literally qualify as redemptions under $\S 317$ (b) would be governed by $\S 302$ (d), 
generated "active business"16 and "device"17 provisions and at least eighty per cent of the controlled corporation's voting stock and eighty per cent of all its other classes of stock are distributed. ${ }^{18}$

The treasury regulations and practices construing these statutory restrictions, while insuring disqualification of tax avoidance manipulations, threaten undue constriction of the nonrecognition principle upon which section 355 is premised. The history of divisive reorganizations under the Internal Revenue Code demonstrates that the basic policy of the current section is nonrecognition of gain or loss in bona fide corporate divisions. ${ }^{19}$ Preclusion of tax avoidance is, of course, an integral factor in effectuating any nonrecognition policy. And a restrictive statutory scheme furnishes a framework for accomplishing this aim. In the area of divisive reorganizations, however, elaborate statutory restrictions combine with the typically large monetary amounts involved to make it imperative for corporations to obtain favorable rulings from the Internal Revenue Service before attempting prospective splits or spins. ${ }^{20}$ Thus the Commissioner's power in this field is unusually pronounced, and implementation of the basic policy of nonrecognition is as likely to depend on treasury regulations and practices as on the language of the statute. Certain of the present regulations and practices may deny the benefits of section 355 to transactions which,

"redemptions treated as distributions of property," and, accordingly, would be subject to the tax consequences imposed by $\S 301$.

Section 355, however, does not purport, nor was it intended, to do anything more than prevent nonrecognition for transactions which fail to meet its requirements. Attributing to a nonrecognition statute the effect of governing methods of recognition would upset the rationale of such sections. See Lyons, Some Problems in Corporate Separations Under the 1954 Code, 12 TAx L. REv. 15, 24 (1956), which also rejects the necessity for uniform treatment, as unsupported by the language of the statute, committee reports or regulations. Lyons further points out that "the statute does not treat even qualifying separations uniformly in all respects." Ibid. See note 10 supra concerning the tax premium $\$ 356$ accords to "boot" received in split, as opposed to spin, transactions.

16. See p. 44 infra.

17. See p. 52 infra.

18. See p. 55 infra.

19. Congress, enacting the Revenue Act of 1924, recognized the economic equivalence and neutrality of spin-offs, split-offs and split-ups, and accorded all divisive forms nonrecognition treatment. S. REp. No. 398, 68th Cong., 1st Sess. 15 (1924). Prior to 1934, however, notable misuses of the reorganization provisions were effected by spin-off distributions. See, e.g., Gregory v. Helvering, 293 U.S. 465 (1935). Gregory had not been finally decided when the Revenue Act of 1934 was being considered, and absent judicial relief, Congress deprived spin-off distributions of the benefits of the reorganization provisions. See note 6 supra and accompanying text. But in considering 1951 amendments to the 1939 Code, Congress finally concluded that nonrecognition treatment for all methods accorded with sound economic policy: "This section [112(b)(11), see note 8 supra] has been included in the bill because your committee believes that it is economically unsound to impede spin-offs which break-up businesses into a greater number of enterprises, when undertaken for legitimate business purposes." S. REP. No. 781, 82d Cong., 1st Sess. 58 (1951). For a complete history of divisive reorganizations under the Revenue Acts see, 3 Mertens, Federal Income Taxation $\$ 20.101$ (rev. ed. 1957).

20. Peterson, supra note 1. 
designed to perpetuate the original business and shareholder interest in modified corporate forms, in fact complement the legislative policy. This Comment will consider the major statutory restrictions, their aims and their compatibility with the position of the Internal Revenue Service.

\section{Active Business Rule}

Section $355(\mathrm{~b})$ (1) provides that a distribution pursuant to a corporate division shall be nontaxable only if,

"(A) the distributing corporation, and the controlled corporation (or, if stock of more than one controlled corporation is distributed, each of such corporations), is engaged immediately after the distribution in the active conduct of a trade or business, or

(B) immediately before the distribution, the distributing corporation had no assets other than stock or securities in the controlled corporations and each of the controlled corporations is engaged immediately after the distribution in the active conduct of a trade or business." 21

A corporation is considered "controlled" when eighty per cent of its voting stock and eighty per cent of all its other classes of stock are owned by the distributing corporation immediately before the distribution. ${ }^{22}$ In requiring only that controlled corporations be actively engaged in business after the distribution, section 355 (b) (1) (B) is intended to be applicable exclusively to splitups, in which the distributing corporation is to liquidate completely. ${ }^{23}$ The requirement that the distributing corporation have no assets other than stock in the controlled corporations is designed to frustrate bail-out schemes which could be effectuated if the distributing corporation were permitted to retain liquid and unrelated assets representing earnings and profits. ${ }^{24}$ Absent this restriction, such retained assets could be distributed to stockholders at capital gains rates in the subsequent complete liquidation under section $331 .{ }^{25}$ Section 355 (b) (1) (A), on the other hand, is intended to govern only spin-offs and split-offs, in which the distributing corporation remains in business after the distribution.

21. InT. Rev. CoDE of 1954, §§ 355(b) (1) (A), (B).

22. Id. $\S 368$ (c), made applicable to divisive reorganizations by $\S 355$ (a) (1) (D) (ii).

23. Although $\S 355$ (b) (1) (B) does not specifically exclude spin-offs and split-offs, no other interpretation would be reasonable. Section 355 (b) (1) (B) does not require the distributing corporation to be engaged in active business after the distribution. Thus, if spinoffs and split-offs, in which the distributing corporation remains in existence after the distribution, were permitted under $\S 355(\mathrm{~b})(1)(B)$, the active business rule could always be avoided. See S. REp. No. 1622, 83d Cong., 2d Sess. 268 (1954).

24. "It is assumed that in connection with the requirement of 'no asset' a de minimis rule will be applied." Ibid.

25. INT. Rev. CODE OF 1954, § 331 (a) (1), provides that "amounts distributed in complete liquidation of a corporation shall be treated as in full payment in exchange for the stock." Section 301, which provides for the taxation of corporate distributions as dividend income, is made inapplicable to complete liquidations by $\$ 331(\mathrm{~b})$. Accordingly, U.S. Treas. Reg. $\$ 1.331-1$ (b) (1955) states that gain or loss will be subject to the capital gains provisions of $\$ \S 1201-23$. 


\section{Active Business Defined}

The necessary elements of a section 355 active business are not delineated by the Code but are posited by the treasury regulations. The statutory requirement was principally designed to prevent the distribution of earnings and profits at capital gains rates through the complete liquidation of a corporation which had participated in a division while holding assets that were liquid or not directly related to the income producing activity of the business. ${ }^{26}$ To insure

26. See note 25 supra. Knapp \& Repetti, supra note 15, at 795.

A corporation probably could not avoid this precaution by conducting a partial liquidation, as defined by $\$ 346$, under $\$ 331$. Section 346 provides for three basic types of partial liquidations. The first, "a series of distributions in redemption of all of the stock of the corporation pursuant to a plan," $\$ 346$ (a) (1), constitutes, in effect, a complete liquidation and would not be used to effect a bail-out unless unwanted assets were first isolated in a new corporate entity. The second, $\$ 346(\mathrm{~b})$, must result in the termination of an entire business and is subject to the same active business requirements as those provided in $\S 355$. While $\S 346(b)$ does not require a showing that the transaction "was not used principally as a device for the distribution of earnings and profits," $\S 355$ (a) (1.) (B), elements of the "device" provision might still be applicable to partial liquidations. This restriction will be employed to disqualify corporate divisions under $\$ 355$ in which either the distributing or controlled corporation retains excessive quantities of liquid or unrelated assets. U.S. Treas. Reg. $\S 1.355-2$ (b) (3) (1955). Similarly, partial liquidations are not likely to qualify for capital gains treatment under $\$ 346(\mathrm{~b})$ if an excessive quantity of such assets are distributed to stockholders. See U.S. Treas. Reg. $\S 1.346-1$ (b) (1955). For a discussion of the applicability of $\$ 355(a)$ (1) (B)'s proscription of prearranged sales to partial liquidations see notes 57-60 infra and accompanying text.

The third type of partial liquidation-redemptions of stock which are "not essentially equivalent to a dividend," $\$ 346$ (a) (2)-is strictly regulated by genuine "corporate contraction" tests. For example, the partial liquidation must derive from continued decline in sales, e.g., Samuel A. Upham, 4 T.C. 1120 (1945), competition causing a permanent retrenchment in corporate operations, e.g., Commissioner v. Champion, 78 F.2d 513 (6th Cir. 1935), or abandonment of product lines, e.g., Commissioner v. Babson, 70 F.2d 304 (7th Cir. 1934). Distributed surplus not reasonably attributable to the contracted part of a business is ineligible for capital gains treatment. U.S. Treas. Reg. § 1.346-1 (a) (1.955) ; Estate of Charles D. Chandler, 22 T.C. 1158 (1954), aff'd, 228 F.2d 909 (6th Cir. 1955). Furthermore, in determining whether distributions qualify for capital gains treatment as partial liquidations, the courts have frequently applied business purpose requirements. See, e.g., Commissioner v. Sullivan, 210 F.2d 607 (5th Cir. 1954); Joseph W. Imler, 11 T.C. 836 (1948). But see Bittker \& Redlich, Corporate Liquidations and the Income Tax, $5 \mathrm{~T}_{\mathrm{Ax}}$ L. REv. 437, 470-73 (1950) (criticizing this approach). For a complete analysis of partial liquidations under the 1954 Code see Bittker, Stock Redemptions and Partial Liquidations Under the Internal Revenue Code of 1954, 9 Stan. L. Rev. 13 (1956) ; Brodskey, Partial Liquidation: Defintion of Partial Liquidation and Rules for Determining Termination of a Business, N.Y.U. 15TH INST. oN FED. TAX. 539 (1957) ; Silverstein, Stockholder Gains and Losses on Partial Liquidation, N.Y.U. 14TH INST. ON FED. TAX. 707 (1956).

Another method of bailing-out liquid and unrelated assets might be a distribution of all corporate assets in complete liquidation followed by the reincorporation of only the active business assets. While aware of this possibility, Congress considered that it would be adequately foreclosed by the Commissioner and the courts:

"The House bill in section 357 contained a provision dealing with a device whereby it has been attempted to withdraw corporate earnings at capital gains rates by distributing all the assets of a corporation in complete liquidation and promptly reincorporating the business assets. This provision gave rise to certain technical prob- 
that transactions facilitating such bail-out distributions are removed from the protection of section 355 , the regulations state that an active business must consist of a "specific existing group of activities" conducted for profit and "must include every operation which forms a part of, or a step in, the process of earning income or profit from such group."27 Although this definition properly assumes that the potential business loss would deter a corporation from liquidating an active and profitable part of its business to bail-out earnings to its stockholders, it suggests a mechanical distinction between horizontally and vertically integrated businesses.

The examples illustrating the regulations' definition strengthen this suggestion even though a horizontal-vertical distinction need not reinforce the deterrence theory. Divisions of horizontally integrated businesses such as men's clothing stores or ice cream factories receive tax-free treatment under section 355..$^{28}$ Divisions of vertically integrated businesses such as a steel mill and its

lems and it has not been retained in the bill as recommended by the accompanying conference report. It is the belief of the managers on the part of the House that, at the present time, the possibility of tax avoidance in this area is not sufficiently serious to require a special statutory provision. It is believed that this possibility can appropriately be disposed of by judicial decision or by regulation within the framework of the other provisions of the bill."

H.R. Rep. No. 2543, 83d Cong., $2 d$ Sess. 41 (1954). In response, U.S. Treas. Reg. $\$ 1.331-$ 1(c) (1955) provides: "A liquidation which is followed by a transfer to another corporation of all or part of the assets of the liquidating corporation or which is preceded by such a transfer may, however, have the effect of the distribution of a dividend or of a transaction in which no loss is recognized and gain is recognized only to the extent of 'other property.' See sections 301 [dividends] and 356 [boot]." For criticism that neither Congress nor the Treasury has sufficiently safeguarded against this device see, Lyons, supra note 15, at 25-26.

27. U.S. Treas. Reg. $\S 1.355-1$ (c) (1955). The regulations further provide that: "Such group of activities ordinarily must include the collection of income and the payment of expenses. It does not include-(1) The holding for investment purposes of stock, securities, land or other property ... (2) The ownership and operation of land or buildings all or substantially all of which are used and occupied by the owner in the operation of a trade or business, or (3) A group of activities which ... are not ... independently producing income...."

28. U.S. Treas. Reg. § 1.355-1(d), Examples (10), (8) (1955).

Permissible divisions of other horizontally integrated businesses are illustrated by id. at Example (15) - electrical equipment factories-and by id. at Examples (13), (14) steel container factories. Accordingly, a spin-off by one branch of a business producing and selling air conditioners of another branch manufacturing electronic products was ruled nontaxable. Rev. Rul. 139, 1954-1 Cum. Burl. 105. The Internal Revenue Service has also accorded nonrecognition treatment to: a spin-off of the main division of a banking business and its branch offices, Rev. Rul. 270, 1953-2 Cum. BuLl. 35; a split-off of poultry business operating in several states, Rev. Rul. 344, 1956-2 CuM. BuLc. 195; and a separation of metal working and electrical trade magazine publishing businesses, Rev. Rul. 451, 1956-2 Curr. Burz. 208. Similarly, a division of hardware and appliance businesses qualified under $\S 355$, Rev. Rul. 117, 1956-1. CuM. BuLl. 180, as did the separation of a typesetting-electroplating concern and another printing business, Rev. Rul. 450, 1956-2 Cur. BuzL. 201. More recently a divisive reorganization of a hotel business and real estate activities was ruled permissible. Caplin, Corporate Division Under the 1954 Code: A New Approach to the Five-Year "Active Business" Rule, 43 VA. L. Rev. 397 (1957). 
supplying coal mine or manufacturing and selling operations are excluded from the section by the regulations. ${ }^{29}$ But since the ownership of distributing or supplying assets may be more valuable to a corporation than a horizontally integrated sector of its business, an inflexible vertical-horizontal dichotomy would be unrealistic. Case by case examination of the nature and relative percentage components of the assets seems a better approach. For example, if the percentage of liquid assets substantially exceeds an amount necessary to finance the active part of a spun-off business, or if the spun-off business consists mainly of unrelated or dormant assets, the distribution of stock in such business should not escape taxation. On the other hand, if the spun-off assets compose an established business activity, independently capable of producing income, the corporate division should be within the scope of section 355 despite the inclusion of a reasonable amount of working capital. ${ }^{30}$ Utilization of this approach would supply needed flexibility to the section as well as subserve the basic policy of nonrecognition.

\section{The Five Year Requirement}

Section 355 (b) (2) (B) requires the trade or business to have been "actively conducted throughout the five year period ending on the date of distribution." The business need not be actively conducted by the distributing corporation during any part of the five year period, but if it was acquired in a taxable transaction-by purchase of stock or assets-the advantage of section 355 is denied. ${ }^{32}$ This restriction on taxable acquisitions prevents a corporation from bailing-out accumulated earnings by obtaining assets not integral to the business and dis-

29. U.S. Treas. Reg. § 1.355-1(d), Examples (12), (11) (1955).

Examples of other vertically integrated divisions which are denied tax-free treatment include manufacturing from research activities, $i d$. at Example (5), and an automobile manufacturing business from an executive dining room operated for profit, $i d$. at Example (16). Thus, corporate division of bakery, creamery, and grocery chain businesses was ruled nontaxable, but the spin-off of real estate activities connected with the grocery chain operations was denied nonrecognition treatment. Rev. Rul. 266, 1956-1 CuMr. Bull. 184.

Several commentators have thought that a vertically integrated sector of a business could qualify under $\$ \mathbf{3 5 5}$ if held for five years by the distributing corporation as an operating subsidiary. See, e.g., Dean supra note 10, at 578. Neither the courts nor the Internal Revenue Service, however, have decided this question. See Lyons, supra note 15 , at 21 \& ก.24.

30. See Rev. Rul. 557, 1956-2 CuMr. Burx. 199, wherein Commissioner ruled that $11.4 \%$ retention of liquid assets did not warrant disqualification. See also Rev. Rul. 554, 1956-2 Cum. Bulz. 198.

31. Int. Rev. CoDE of 1954, $\$ 355$ (b) (2) (B).

32. Id. $\S 355$ (b) (2) :

"[A] corporation shall be treated as engaged in the active conduct of a trade or business if and only if - ... (C) such trade or business was not acquired within [five years of the distribution] ... in a transaction in which gain or loss was recognized in whole or in part, and (D) control of a corporation which (at the time of acquisition of control) was conducting such trade or business-(i) was not acquired directly (or through one or more corporations) by another corporation within [five 
tributing stock in the newly acquired, or formed, controlled corporation holding such assets to shareholders who may liquidate it at capital gains rates.

The rules provided by the conference committee report for determining whether a trade or business has been conducted for the requisite five year period emphasize the nature of any change undergone by the separated businesses. Imposition of a five year requirement upon the active business rule furnishes a safeguard against distribution of profits at capital gains rates similar to that afforded by the disqualification of businesses purchased within five years. $^{33}$ While corporations are not likely to bail-out earnings at the cost of losing an established or "aged" business, they might view division as a means of enabling their stockholders to liquidate a business consisting of assets recently acquired with surplus cash, which are not directly related to the older business. ${ }^{34}$ Thus, the report states that the five year active conduct requirements will be fulfilled "even though such trade or business underwent change during such five year period, for example, by the addition of new, or the dropping of old, products, changes in production capacity, and the like, provided the changes are not of such a character as to constitute the acquisition of a new or different business." 35

Although the regulations incorporate this rule in almost identical language, ${ }^{30}$ the Internal Revenue Service has informally indicated that a stricter test is applied. An expanded business will qualify under the five year rule when its fiveyear-and-over assets carry a net adjusted basis of more than fifty per cent of all the assets in the business, have a net fair market value of more than fifty per cent

years of the distribution] ... or (ii) was so acquired by another corporation within such period, but such control was so acquired only by reason of transactions in which gain or loss was not recognized in whole or in part, or only by reason of such transaction combined with acquisitions before the beginning of such period."

Accordingly, businesses acquired by taxable purchases of assets ( $\$ 355(\mathrm{~b})(2)(\mathrm{C})$ ) or stock ( $\$ 355$ (b) (2) (D)) during the five year period are ineligible for nonrecognition treatment, even when such businesses are acquired indirectly by a subsidiary of the distributing or controlled corporation. See H.R. Rep. No. 2543, 83d Cong., 2d Sess. 37-38 (1954) ; U.S. Treas. Reg. $\$ \S 1.355-4$ (b) (1), (2) (1955). The statutory requirement that no gain or loss have been recognized on acquisitions contemplates transactions which were tax-free despite accrual of gain, rather than those which were nontaxable because gain was not realized. 3 Mertens, Federal Income Taxation $\$ 20.103$, at 451 (rev. ed. 1957).

33. INT. REv. CODE of 1954, $\$ 355$ (b) (2) (C), precludes the outright purchase of a business, while $\$ 355$ (b) (2) (B) - the five year rule-prevents the gradual acquisition of a new or different business.

34. See Brodskey, supra note 26 , at 546 .

35. H.R. Rep. No. 2543, 83d Cong., 2 d Sess. 38 (1954).

Commencement of a business, while significant in determining the five year period, is nowhere defined. A possible analogy could be found in rules determining the beginning of a depreciation period. See U.S. Treas. Reg. $\$ 1.167$ (a)-10(b) (1955). Commencement might also be dated from the first substantial acquisition of assets or from the first accrual of gross income. A more liberal approach would be to recognize the period of exploration, research and development within the five year requirement. Brodskey, supra note 26 , at 555.

36. U.S. Treas. Reg. § 1.355-4(b) (3) (1955). 
of such assets and will produce more than fifty per cent of the projected net income of the business. ${ }^{37}$ These fifty per cent tests are inconsistent with both the committee report and the regulations. For compliance is measured solely by the extent of business change; the nature of such change is apparently disregarded.

Testing an expanded business by the nature rather than extent of its change would be more consistent with the policy of the five year rule. The significance which the fifty per cent rules import to the extent of change penalizes natural business evolution and business growth. ${ }^{38}$ Moreover, alteration of an established business in response to variations in market demand would seem to demonstrate an intent to remain in business more than a motive to liquidate for the purpose of a bail-out. Similarly, the fact that a business is expanding would appear to make the possibility of a liquidating bail-out more remote. For example, a business manufacturing men's hats for over five years might respond to a style change by converting, or expanding, its operations to the production of caps. Or, it might expand or convert to the manufacture of shoes. Assuming, in each situation, that the new assets necessary for such production constituted more than fifty per cent of the total assets, only the latter change should effect disqualification under the five year rule. This rule postulates that an established business is less likely to be the instrument of a bail-out than a new business. Accordingly, change should disqualify a corporate division only when it materially alters the nature, and thus the "established" character, of a five year active business. ${ }^{39}$ More generally, the fifty per cent requirements defeat the

37. Caplin, Corporate Separations: The 5-Year Business Rule, N.Y.U. 15TH INST. on FED. TAX. 623, 633-34 (1957) (compliance with only two of the 50\% tests might satisfy active business requirements). See also note 39 infra. Pursuant to the five year active business test imposed by the partial liquidation definition of $\S 346$, "an asset shall be considered used in the trade or business during the period of time the asset which it replaced was so used . ..." U.S. Treas. Reg. $\S 1.346-1$ (b) (2) (i) (1955). Moreover, inventory satisfied the five year requirement if "(a) The items constituting such inventory ... were substantially similar to the items constituting such inventory . . . during the fiveyear period immediately before distribution, and (b) The quantity of such items on the date of distribution was not substantially in excess of the quantity of similar items regularly on hand in the conduct of such business during such five-year period . . . " U.S. Treas. Reg. $\S 1.346-1$ (b) (2) (iii) (1955). While these regulatory standards are not specifically made applicable to $\S 355$, their use would ameliorate the strictness of the $50 \%$ tests.

38. Caplin, Corporate Separations: The 5-Year Business Rule, N.Y.U. 15Te INST. oN FED. TAX. 623, 634 (1957).

39. A recent ruling reported in Caplin, Corporate Division Under the 1954 Code: $A$ Neze Approach to the Five-Year "Active Bisiness" Rule, 43 VA. L. Rev. 397, 401-02 (1957), suggests some relaxation of the $50 \%$ tests. A corporation engaged in rental and hotel businesses sought to spin-off the latter operation. While newly acquired realty comprised less than $50 \%$ of all rental assets on a net fair market value comparison, the lessthan-five-year assets failed to meet other $50 \%$ tests with respect to net adjusted basis and projected net income. Nevertheless the Service ruled that the proposed division would satisfy $\S 355$ :

"The purpose behind the five year limitation in section 355 is to prevent corporate earnings of one business from being drawn off for such a period and put into a new 
purpose of the five year rule merely because they are percentage tests-a factor demonstrated by their concurrent application with the attribution rule.

\section{Attribution Rule}

Section 355 (b) (2) (A) provides an alternative to the requirement that a corporation itself be engaged in the active conduct of a trade or business. The active business test is satisfied by the controlled or distributing corporation if "substantially all of its assets consist of stock and securities of a corporation controlled by it (immediately after the distribution) which is so engaged." 40 "Substantially all" is not defined by the Code or the Regulations. However, in judg-

business and thereby, through the creation of a marketable enterprise, convert what would normally have been dividends into capital assets that are readily salable by the shareholders. It is the position of this office that where a corporation which is devoted to one type of business also engages in a rental business, and substantial acquisitions of new rental property are made within the five year period preceding the separation of these businesses, a spin-off transaction will not qualify under section 355 unless it can be shown that the property acquisitions are substantially financed out of the earnings of the rental business and not out of the earnings of the other business.

In the instant case, it is evident that there has been a very substantial increase in the rental business of [Old Corp.] within the past five years measured both in terms of property acquired and income derived therefrom. However, an analysis of the detailed information submitted in support of the request for ruling indicates that these property acquisitions were not substantially financed out of the earnings of the hotel business... . The acquisition of new rental properties in the past five years was financed primarily with borrowed money. On the basis of the division of properties proposed, the hotel business will be in practically the same position it would be if five years ago the hotel properties and its allocable share of the nonbusiness or investment assets had been separated and it had retained all of its subsequent earnings.... Thus, no substantial part of the recent acquisition of rental property appears to have been financed out of the earnings of the hotel business on the basis of the proposed division of assets." (Emphasis added.)

Accordingly, an operation's inability to qualify under two $50 \%$ standards will not preclude tax-free treatment if its more recent acquisitions were not "substantially financed" from another operation's earnings and profits.

This alternative te'st, while affording some flexibility, no more complements the nature of business change approach endorsed by committee reports than do the $50 \%$ requirements. The Treasury's insistence that growth generate from a business' own resources is designed to prevent corporations from furbishing loss divisions with marketable assets purchased with the accumulated earnings of a profitable branch of the business. For the Service most likely considers that spinning-off businesses financed in this manner would facilitate bail-outs through subsequent complete liquidations under $\S 331$. However, such devices would be forecasted inaccurately unless the Commissioner examines the relationship between newly acquired assets and the character of the five year business. Recent acquisitions not changing the nature of an established business, but in fact representing propitious evolution or growth, should not be interpreted as evidencing tax avoidance motivation. Thus such expansion should not preclude nonrecognition treatment whether financed from the business' own funds, by an outside agency or from the earnings of another branch of the corporation.

40. INT. REv. CODE of 1954, § 355(b) (2) (A). 
ing prospective combinative reorganizations in which "substantially all of the properties" of one corporation must be exchanged for voting stock in another, the Internal Revenue Service has defined "substantially all" as not less than ninety per cent, under both the 1939 and the 1954 Codes.41 Accordingly, its utilization of a similar definition for section 355 seems likely.

While a ninety per cent attribution rule would curtail tax avoidance schemes, it would interact with the fifty per cent requirements to produce the inconsistent results inherent in percentage tests. Presumably, the "substantially all" rule is designed to prevent the isolation of nonactive business assets in either the distributing or controlled corporation and thus to impede a subsequent liquidating distribution of accumulated earnings to stockholders at capital gains rates. Certainly, a ninety per cent rule would accomplish this end. On the other hand, joined with the fifty per cent requirements, it would allow holding company divisions in situations where direct divisions would not qualify. For example, if ninety per cent of corporation $A$ 's assets consist of the controlling stock of corporation $B$, and fifty per cent of $B$ 's assets have been engaged in active business for five years, $A$ qualifies as an active business. After a division, $A$ could liquidate its subsidiary $B$ without tax consequence under section $332.42 A$ would then be in the same position as a corporation which had qualified under the fifty per cent tests alone. But it would have less than fifty per cent active business assets. If the fifty per cent tests accurately measure tax avoidance motivation, $A$ would have no objective other than complete liquidation and distribution of earnings to stockholders at capital gains rates. The attribution and five year business rules would have thus combined to produce the very result they were designed to prevent. Moreover, this result must occur so long as the Commissioner uses a percentage definition of the active business restriction. Section 355 (b) (2) (A) defines active business identically for all operating corporations, whether or not they are subsidiaries. ${ }^{43}$ And the attribution rule, requiring "substantially a1l," must involve a percentage testa test by definition utilizing a percentage less than one hundred. Mathematically, therefore, holding company structure will always portend tax avoidance when active business is defined in percentage terms.

While eliminating the fifty per cent requirements would remove this anomaly, relaxation of the "substantially all" rule is also indicated. The five year rule

41. Id. $\$ 368(\mathrm{a})(1)(\mathrm{C})$; Int. Rev. Code of 1939 , $\$ 112(\mathrm{~g})(1)(\mathrm{C})$, as amended, 58 Stat. 43 (1944).

Private rulings issued by the Internal Revenue Service reflect the "not less than $90 \%$ " definition of "substantially all" under the combinative reorganization provisions. Moreover, the Internal Revenue Service has informally indicated that this definition was and is regularly applied under the 1939 and 1954 Codes in judging combinative reorganizations at the advance ruling stage.

42. INT. REv. CoDE of 1954, $\S 332$, provides for the nonrecognition of gain or loss in the complete liquidation of a subsidiary by a parent corporation owning $80 \%$ of the subsidiary's voting stock plus $80 \%$ of all its other classes of stock.

43. A corporation complies with $\$ 355(\mathrm{~b})(2)(\mathrm{A})$ if "it is engaged in the active conduct of a trade or business," or if it controls a corporation which is "so engaged." 
should test the nature rather than extent of business assets so that corporations expanding existing facilities need not be deprived of the benefits of section 355.44 In addition, the "substantially all" rule should be flexible. Holding companies failing to meet a ninety per cent requirement may lack sufficient liquid and unrelated assets to pose a bail-out problem. Inflexibility does not appear a justifiable ground for denying them tax-free divisive reorganizations. Moreover, the statutory and judicial "device" restrictions can combine with a flexibly applied "substantially all" rule to insure disqualification of tax avoidance manipulations.

\section{Statutory Device Provisions}

Reinforcing the objective requirements of section 355 is the comprehensive restriction against transactions "used principally as a device for the distribution of earnings and profits." 45 The regulations construing this condition incorporate the rules of business purpose developed in cases judging the taxability of combinative reorganizations. ${ }^{46}$ Particular consideration is also given to the nature, kind and amount of assets held by all corporate parties to the separation. ${ }^{47}$ Thus, the character of business assets will be re-examined in accordance with device precautions, and the permissible ratio of working capital will be measured with reference to business needs. Predominant among device safeguards is the additional proscription against employing section 355 to effect nontaxable sales of corporate assets.

\section{Bona Fide Divisions or Taxable Sales}

Section 355 (a) (1) (B) permits nontaxable divisions only if, "the transaction was not used principally as a device for the distribution of ... earnings and profits ... (but the mere fact that subsequent to the distribution stock or securities in one or more [corporate parties to the division] ... . are sold or exchanged by all or some of the distributees (other than pursuant to an arrangement negotiated or agreed upon prior to such distribution) shall not be construed to mean that the transaction was used principally as such a device)."48

According to the regulations, a sale is pursuant to a prior agreement "when enforceable rights to buy or to sell exist before such distribution." ${ }^{49}$ However, the Internal Revenue Service indicates that a prior negotiation will be presumed when a subsequent sale was discussed before the distribution. ${ }^{50}$ Several com-

44. See text at notes 38,39 supra.

45. INT. Rev. CODE OF 1954, § 355 (a) (1) (B).

46. U.S. Treas. Reg. $\$ 1.355-2$ (c) (1955).

47. U.S. Treas. Reg. $\$ 1.355-2$ (b) (3) (1.955).

48. INT. REv. CODE of 1954, § 355(a) (1) (B).

49. U.S. Treas. Reg. $\$ 1.355-2$ (b) (2) (1955).

50. U.S. Treas. Reg. $\S 1.355-2$ (b) (1) (1955) states: "If, pursuant to an arrangement negotiated ... prior to the distribution of stock or securities of the controlled corporation, part or all of the stock or securities of either corporation are sold or exchanged 
mentators have severely criticized this reasoning on the ground that the main purpose of the outer parenthetical clause was to negate an inference and that the inclusion of the inner exception ought not to create one. ${ }^{51}$ These criticisms do not seem warranted in light of the policy underlying the inner qualification.

The statutory and regulatory preclusion of prior negotiation transactions from the protection of section 355 prevents a corporation which intends to sell appreciated assets from effecting this transaction under the guise of a tax-free divisive reorganization. In the absence of such restrictions, a corporation could spin-off the assets to be sold after arranging a sale of the stock to be distributed with the intended purchaser. Since such a transaction is likely to require prior negotiations, the corporate division will probably not qualify under section 355 . Thus, when shareholders sell the stock in the spun-off corporation, the distributing corporation will be taxed on the difference between the basis and sales price of the spun-off assets. ${ }^{52}$ And the original distribution will be taxed as a dividend to the distributees. ${ }^{53}$ Although this result cannot be explained in terms of tax policy at the shareholder level-presumably the same transaction effected as a partial liquidation would give rise to capital gains ${ }^{54}$-it can be justified as preventing tax avoidance at the corporate level.

after the distribution, such sale or exchange will be evidence that the transaction was used principally as a device for the distribution of the earnings and profits of the distributing corporation or of the controlled corporation, or both." Accordingly, in Rev. Rul. 103, 1955-1 Cus. Burc. 31, 32, the Commissioner stated, "the sale of stock of the distributing corporation immediately subsequent to a distribution of stock of a controlled corporation, when negotiations for such a sale are already in process, is generally considered sufficient evidence that the distribution of stock was used principally as a device for the distribution of earnings and profits of the distributing corporation." 3 MERTENs, FeDERAL INCOME TAXATION $\$ 20.102$, at 446 (rev. ed. 1957) ("where the sale or exchange has been negotiated ... prior to the distribution, there seems to be little chance that the distribution will be deemed to come within Section 355"); Cohen, Silverman, Surrey, Tarleau \& Warren, The Internal Reveme Code of 1954: Corporate Distributions, Orgatizations, and Reorganizations, 68 HARv. L. REv. 393, 432 (1955) ("presumably, a sale pursuant to such prior negotiations ... will automatically disqualify the distribution"). Moreover, Dean, Spin-offs: General Rules; Requirements as to Active Business; Some Practical Considerations (Section 355), N.Y.U. 15TH INST. on FED. TAX. 571, 586 n.47 (1957), discloses "the Internal Revenue Service has indicated that any premeditated disposition of the stock may void the spin-off even though the disposition be in the form of a tax-free exchange under the reorganization provisions [§ 368]."

51. Peterson, Subchapter C of the Internal Revemue Code of 1954 III. Corporate Organizations and Reorganizations, 30 Notre Dame Law. 617, 650 (1955). See Dean, supra note 50 , at $585-86$.

52. Amounts realized on such sales will be accorded capital gains treatment if all of the corporation's $\S 1231$ transactions for the year show a net gain. BITTKER, FEDERAL InConfe Estate AND Gift TAxation 406 (1955). Failing to qualify under $\$ 1231$, sales of corporate assets generally give rise to ordinary income unless specifically protected under nonrecognition sections. See InT. Rev. Code of 1954, \$ 1221; Commissioner v. Court Holding Co., 324 U.S. 331 (1945) ; United States v. Lynch, 192 F.2d 718 (9th Cir. 1951), cert. denied, 343 U.S. 934 (1952).

53. See note 15 supra.

54. INT. REv. CODE OF 1954, §§ 331, 346. 
Removing prior negotiation transactions from nonrecognition treatment under section 355 will probably foster attempts to effectuate sales under the partial liquidation provisions of sections 331 and 346. If all of section 355's requirements other than the prior negotiation provision could be fulfilled, the parties seemingly could execute a sale with minimum tax consequence under section 346 (b)..$^{55}$ For example, if the selling corporation distributed, in redemption of part of its stock, a qualified active business in kind to its stockholders, the distribution would result, under section 331 , in capital gain to the distributees. Upon the sale of such business, the stockholders would not recognize additional gain; presumably, the sales price would establish the fair market value governing the amount of gain realized on the partial liquidation. ${ }^{50}$

Application of the Court Holding doctrine or extension of the section 355 proscription of prior negotiation transactions would result in tax recognition at the corporate level despite utilization of the partial liquidation technique. In Commissioner v. Court Holding, the corporation was taxed on an ultimate stockholder sale because of evidence that the corporation had negotiated the sale prior to its liquidation. ${ }^{57}$ Since a public corporation generally must negotiate a sale of assets on behalf of its many stockholders, sale transactions in such corporations will ordinarily be taxable under Court Holding. ${ }^{58}$ In the case of closely-held corporations, however, the stockholders could negotiate their own sales. And, under the Cumberland rule, such stockholder negotiations would obviate corporate tax liability. ${ }^{59}$ On the other hand, section 355 , while not dealing with partial liquidations, labels any prior negotiation transaction as a $\operatorname{tax}$ avoidance device. This elimination of the artificial distinction between actions in director and shareholder capacities conceivably represents a statutory overruling of Cumberland and might be applied to prior negotiation devices attempted under another section. ${ }^{60}$

55. Id. $\$ 346$, which defines a partial liquidation, contains the five year active business requirement, $\S 346(\mathrm{~b})$, but does not have the statutory device provision found in $\S$ 355 (a) (1) (B).

56. Stinson \& Antroine, Tax-Free Exchanges 36 (PLI Fundamentals of Fed. Tax. ser. 1956).

57. 324 U.S. 331 (1945).

58. See $i$ bid.

59. United States v. Cumberland Pub. Serv. Co., 338 U.S. 451 (1950), wherein the Court held that partial liquidation and shareholder sale of assets following corporate rejection of proposed sale was nontaxable to the corporation: "[A] corporation is taxed if it sells all its physical properties and distributes the cash proceeds as liquidating dividends, yet is not taxed if that property is distributed in kind and is then sold by the shareholders." $I d$. at $454-55$.

60. In providing for tax-free corporate sales in complete liquidations, INT. REv. CODE OF 1954, § 337, Congress disapproved the Court Holding-Cumberland distinction:

"Your committee follows the House bill in eliminating questions arising as a result of the necessity of determining whether a corporation in process of complete liquidation made a sale of assets or whether the shareholder receiving the assets made the sale. Compare Commissioner v. Court Holding Company (324 U.S. 331) with U.S. v. Cumberland Public Service Company (338 U.S. 451). This last decision holds that 


\section{Distribution of Control}

Section 355 (a) (1) (D) requires the distribution of all stock and securities of the controlled corporation held by the distributing corporation; or, if at least eighty per cent of the voting stock plus eighty per cent of all other classes of stock are distributed, the transaction may qualify upon a showing that the retention of stock is not pursuant to a plan of tax avoidance. ${ }^{61}$ The obvious intent of this subparagraph is to prevent distributee stockholders from selling the stock of the detached corporation while reserving control through their interest in the distributing corporation. ${ }^{62}$ A distinction should be recognized, however, between public and close corporations in regard to the percentage of their stock which can be retained. The distributing corporation's retention of less than twenty per cent of a public corporation may often constitute practical control. Conversely, twenty per cent retention of stock of a closelyheld corporation would rarely facilitate the proscribed tax avoidance, since stock of a closely-held corporation is seldom marketable unless a controlling interest is offered for sale. ${ }^{63}$ Accordingly, a strict interpretation of the eighty per cent

if the distributee actually makes the sale after receipt of the property, there will be no corporate $\operatorname{tax}$ on the sale. The result of these two decisions is that undue weight is accorded the formalities of the transaction and they, therefore, represent merely a trap for the unwary."

S. REp. No. 1622, 83d Cong., 2d Sess. 4S-49 (1954). This language and the enactment of $\$ 337$ might demonstrate congressional dissatisfaction with the Court Holding rule in all contexts. A more persuasive argument, however, would be that the senate report merely acknowledges the artificiality of distinguishing between corporate and shareholder sales negotiated prior to distribution. Thus, once Congress decided to accord nonrecognition to sales pursuant to complete liquidations, it extended such treatment irrespective of whether corporations or shareholders negotiated the transactions. But exclusion of partial liquidation sales from the advantages of $\$ 337$ indicates congressional approval of the tax liability inherent in continued corporate existence. And since Congress has decided to observe the taxability of sales in partial liquidation, imposition of corporate tax on previously negotiated shareholder sales would be consistent with congressional disparagement of the Court Holding-Cumberland distinction. Nevertheless, the Internal Revenue Service plans to follow the Court Holding-Cumberland distinction in partial liquidation transactions. "The determination of whether assets sold in connection with a partial liquidation are sold by the distributing corporation or by the shareholder is a question of fact to be determined under the facts and circumstances of each case." U.S. Treas. Reg. $\$ 1.346-3$ (1955).

61. INT. Rev. CoDe of 1954, § 355(a) (1) (D).

62. See 3 Miertens, Federal Incone Taxation $\$ 20.102$, at 442 (rev. ed. 1957). This distribution restriction does not require, of course, that a distributing corporation own all the stock and securities of a controlled corporation. Presumably, then, distribution of part of a controlled corporation's stock prior to a spin-off distribution will permit qualification under $\S 355$ (a) (1) (D). Id. at n.99. However, a distributing corporation's transfer of stock in the corporation to be spun-off to another controlled subsidiary would most likely be foreclosed as an obvious evasion.

Stock acquired in taxable transactions occurring within five years of distribution is included in the quantum of stock which must be distributed under $\S 355$ (a) (1) (D). See S. Rep. No. 1622, 83d Cong., 2d Sess. 268 (1954) ; U.S. Treas. Reg. $\$ 1.355-2(f)$ (1955).

63. O'Neal, Resolving Disputes in Closely Held Corporations: Intra-Institutional Arbitration, 67 HARv. L. REv. 786, 787 (1954). 
requirement might be unwarranted when the detached corporation is closelyheld.

\section{Business Purpose}

\section{Judicial Device Doctrines}

Courts developed the requirement of "business purpose" to disqualify tax avoidance devices which literally complied with the old reorganization provisions. ${ }^{64}$ The requirement has been incorporated by the regulations which render section 355 inapplicable to transactions "carried out for purposes not germane to the business of the corporations" or not "required by business exigencies." 65 The potential impact of the business purpose rule may best be illustrated by its past application. Corporate divisions intended to separate the interests of disputing stockholder groups, ${ }^{66}$ to insulate the major part of the distributing corporation's assets from the risk of a new venture ${ }^{67}$ or to avoid the burdensome taxes of the charter state on a particular branch of the business have regularly been qualified. ${ }^{68}$ On the other hand, sham transactions not intended to have lasting consequences, ${ }^{69}$ transactions directly benefiting the stockholders rather than the going business ${ }^{\mathbf{7 0}}$ and transactions which have the net

64. 3 Mertens, Federal Incone Taxation $\$ \$ 20.54-.59$ (1957); Paul, Studies in Federal Taxation 90 (3d ser. 1940).

65. U.S. Treas. Reg. $\$ 1.355-2$ (c) (1955). 195.

66. Rev. Rul. 117, 1956-1 Cumr. Bull. 180. See also Rev. Rul. 344, 1956-2 Cunr. Bull.

67. Spangler v. Commissioner, 18 T.C. 976 (1952). See Rev. Rul. 139, 1954-1 CuM. BulL. 105.

68. Spangler v. Commissioner, supra note 67. Cf. C. A. Munroe, 39 B.T.A. 685, 699 (1939).

69. See, e.g., Helvering v. Gregory, 69 F.2d 809 (2d Cir. 1934), aff'd, 293 U.S. 465 (1935) (spin-off of corporation holding only marketable securities as conduit to effect a sale held not to qualify as divisive reorganization) ; Electrical Securities Corp. v. Commissioner, $92 \mathrm{~F} .2 \mathrm{~d} 593$ (2d Cir. 1937) (formation of corporations for purpose of avoiding tax on exchange of stock not accorded tax-free treatment as reorganization) ; Robert M. Morgan, 41. B.T.A. 379 (1940), aff'd, 117 F.2d 334 (2d Cir. 1941) (liquidating dividend in guise of reorganization held taxable).

A reorganization is not necessarily sham if unforeseen circumstances subsequent to qualification negate its effect. Lea v. Commissioner, 96 F.2d 55 (2d Cir. 1938); Michaelson, "Business Purpose" and Tax-Free Reorganization, 61 YAlE L.J. 14, 29 (1952).

70. The distinction between corporate and shareholder purpose was notably presented in Alice H. Bazley, 4 T.C. 897, 904 (1945). While the Third Circuit countenanced the tax court's position, the Supreme Court indicated that this reason for an otherwise proper decision was poorly expressed. Bazley v. Commissioner, 155 F.2d 237 (3d Cir. 1946), aff'd, 331 U.S. 737, 743 (1947). Accordingly, some opinions have renounced a stockholder-corporation dichotomy. Estate of John B. Lewis, 10 T.C. 1080, 1086 (1948), aff'd, 176 F.2d 646, 649-50 (1st Cir. 1949) ; Survaunt v. Commissioner, 162 F.2d 753 (Sth Cir. 1947) (by implication).

The language of U.S. Treas. Reg. $\$ 1.355-2$ (c) (1955), see text at note 65 supra, however, suggests that corporate, as distinct from stockholder, business purpose is essential for qualification under $\$ 355$. Predominant corporate purpose would seem difficult to find in view of $\S 355$ 's basic function of dividing business at the stockholder level. Dean, supra note 
effect of achieving results normally found taxable have been denied nonrecognition treatment. ${ }^{71}$

The combination of the business purpose rule and the statutory restrictions offers flexibility in the qualification of divisive reorganizations. At the ruling stage, transactions fulfilling the objective requirements of the statute can be safely approved. Should such ostensibly legitimate divisions disclose tax avoidance purpose in subsequent stages, the courts can employ the business purpose test to impose proper tax liability. Judicial scrutiny may be given further compass by the step-transaction test-a business purpose derivative.

\section{The Step-Transaction Rule}

When separate transactions constitute an over-all plan, the entire program, not merely the separate steps, must satisfy the reorganization provisions. This requirement, labelled the "step-transaction" or "net-effect" rule, is illustrated by the leading case of Helvering v. Elkhorn Coal Co. ${ }^{72}$ In Elkhorn, corporation $A$ desired to purchase less than substantially all of the assets of corporation $B$. To qualify the transaction under the section then governing combinative reorganizations, ${ }^{73} B$ spun-off the assets not wanted by $A$ to a newly formed corporation $C$, and transferred the remaining assets to $A$ in exchange for twenty-five per cent of $A$ 's voting stock. While the latter step alone qualified as a transfer of substantially all of $B$ 's assets in exchange solely for voting stock, the court properly linked the two steps and held the net effect of the entire plan to be a taxable sale. This doctrine affords the courts an effective weapon against transactions which apparently meet section 355 's requirements but which in later steps indicate a tax avoidance plan. For example, the doctrine might be applied to a series of liquidations conducted within a network of holding companies which had been originally spun-off for the purpose of bailing-out the liquid and unrelated assets of the top holding company. ${ }^{74}$ In

50, at 587. Nevertheless, divisive reorganizations have satisfied corporate business purpose examinations. See notes 66,67 supra. And while some commentators have severely criticized the rule, e.g., Spear, "Corporate Business Purpose" In Reorganization, 3 TAx L. REv. $225,242-43$ (1947), others suggest that the corporate-stockholder dichotomy is consistent with congressional intent, Bittker, What Is "Business Purpose" in Reorganizations?, N.Y.U. Str INST. oN FED. TAX. 134, 141-42 (1950), and the promotion of lasting improvements in corporate financial structure, Michaelson, supra note 69 , at 32.

71. Bazley v. Commissioner, 331 U.S. 737 (1947); Heady v. Commissioner, 162 F.2d 699 (7th Cir. 1947). See Ivins, The Business Purpose Rule in Corporate Recapitalization, N.Y.U. 7TH InST. on FED. TAX. 1161, 1166-67 (1949). See, generally, Schlesinger, Gregory Guards the Code, 28 TAXes 1085 (1950).

72. 95 F.2d 732 (4th Cir.), cert. denied, 305 U.S. 605 (1938). Se'e also Richard K. Mellon, 12 T.C. 90, aff'd, 184 F.2d 157 (3d Cir. 1950).

73. Revenue Act of 1926, § 203 (h) (1) (A), 44 Stat. 14.

74. The attribution rule probably permits either distributing or controlled corporations to control an active business through an intermediate subsidiary. Section 355 (b) (2) (A) provides that "a corporation shall be treated as engaged in the active conduct of a trade or business if ... substantially all of its assets consist of stock and securities of a corporation controlled by it ... which is so engaged." "A corporation" presumably means any 
this event, the net effect of the transaction could be held a taxable dividend to the distributee stockholders. But automatic invalidation based on steps effected to comply with the requirements of section 355 would be undesirable.

Preliminary actions to enable ultimate division often will be entirely consistent with qualification under section 355. On the verbal level, acquisitions of stock in an operating subsidiary to meet the requirement that "substantially all" of a holding company's assets consist of stock in an active business are justifiable. ${ }^{75}$ Sections $355(\mathrm{~b})$ (1) (A) and (B) only require that distributing corporations be engaged in active business after the distribution. ${ }^{70}$ Both sections permit, by the very nature of divisive reorganizations, the transfer of an entire active business to a newly created controlled corporation before distribution. ${ }^{77}$ The attribution rule is plainly subservient to these basic requirements and is also concerned solely with the status which must exist after a distribution. Thus, lesser transfers performed before distribution to meet the attribution requirement should not compel disqualification so long as both distributing and controlled corporations are engaged in active business after distribution.

Moreover, these transfers and the steps taken to comply with the split-up requirement that the distributing corporation have no assets other than stock in the controlled corporations ${ }^{78}$ complement the objectives of section 355 . The Elkhorn line of cases developing the step-transaction rule does not proscribe such preliminary steps. The purpose of holding that substantially all of the transferor's assets must be acquired by the transferee is to insure that the transaction constitutes a true merger, not a sale. When the transferor, like Elkhorn, in effect retains a substantial portion of its assets, though in a new corporate entity, the object of the combinative reorganization provisions would be frustrated if the preliminary steps were sanctioned. ${ }^{79}$ Hence, linking the steps to

corporation. Thus if $90 \%$ of an intermediate holding company's assets consist of stock in an operating subsidiary, it would be considered an active business, see note 41 supra; and if substantially all of the top holding company's assets are composed of stock in the intermediate, it would also seem to be within the requirement.

Holding company structure, however, permits excessive dilution of the interest of a top company in the active business of an operating subsidiary. And through a series of $\S 332$ liquidations the apex corporation could gather an inordinate percentage of liquid and unrelated assets preparatory to a complete liquidation bail-out under $\$ 331$. See notes 25,42 supra and accompanying text. But in the unlikely event of such machinations, the steptransaction rule could be properly employed to tax the final liquidating distribution as dividend income.

75. INT. Rev. Code of $1954, \S 355$ (b) (2) (A).

A holding company's additional acquisitions of stock in a "controlled" subsidiary do not offend statutory requirements. Acquisitions which effect control, however, must be nontaxable to permit qualification. See note 32 supra. A holding company might also step into the "substantially all" requirement by distributing other assets to its subsidiary as a tax-free capital contribution under $\$ 118$. Cf. Rev. Rul. 117, 1956-1 Cun. Bul.. 180.

76. INT. Rev. CoDe of 1954, $\$ 355$ (b) (1) (A), (B) quoted at p. 44 supra.

77. U.S. Treas. Reg. $\$ 1.355-1$ (b) (1955).

78. INT. Rev. CODE of 1954, § 355(b) (1) (B).

79. See Rev. Rul. 103, 1955-1 Cum. Bull. 31, for disqualification of transaction whereby assets not wanted by prospective purchasing corporation were spun-off to meet the substantially all provision of $\$ 368(a)(1)(C)$. 
expose the ultimate merger as a sale is crucial to the imposition of proper tax liability. Similarly, if in order to comply with the "no assets" restriction, the distributing corporation separated business and liquid assets into two controlled corporations, the purpose of section $355(\mathrm{~b})(1)(B)$ would be thwarted if a distribution of stock in the liquid subsidiary were accorded nonrecognition treatment. But this situation is adequately precluded by the active business requirement itself. Furthermore, effecting compliance with the "no assets" and "substantially all" rules through preliminary acquisitions of stock in controlled corporations which are to continue the active business presents no such likelihood of bail-out. ${ }^{80}$ The danger to be guarded against is retention of an unduly large proportion of liquid or unrelated assets by the distributing or controlled corporation, which would facilitate the subsequent removal of accumulated earnings at capital gains rates through complete liquidation. Rather than posing this danger, corporations stepping into the "substantially all" or "no assets" requirements by disposing of liquid assets in exchange for stock actually make the possibility of such tax avoidance more remote. ${ }^{81}$

In addition, steps taken to comply with the attribution and "no assets" rules are supported by the rationale of Commissioner $v$. Day \& Zimmerman, Inc., 82 as are corporate acquisitions of stock for the purpose of qualifying under the control requirement. ${ }^{83}$ In Day \& Zimmerman, the parent corporation successfully avoided the eighty per cent stock ownership requirement in section 112 (b) (6), the 1939 counterpart of section 332 of the 1954 Code, and consequently recognized loss, by selling a portion of its subsidiary's stock immediately before liquidating the subsidiary. ${ }^{84}$ Commissioner v. Granite Trust Co., the most recent affirmance of Day \& Zimmerman, held that a parent which gave away its subsidiary's stock to avoid the nonrecognition provision of section 112 (b) (6) did not violate the step-transaction rule. ${ }^{85}$ Similarly, acquisition of stock sufficient to constitute control of a subsidiary or to conform to the "substantially all" or "no assets" requirements should be approved by the Commissioner and the courts. Indeed, the diminution of bail-out possibilities makes allowing corporations to step into section 355 's requirements in order to obviate tax consequences more reasonable than permitting them to step out of section 332 for the same purpose. ${ }^{86}$

\section{CONCLUSION}

Finding the judicial device doctrines sufficient to insure disqualification of tax avoidance manipulations in the guise of divisive reorganizations, commen-

80. See notes 24,25 supra and accompanying text; p. 51 supra.

81. Ibid.

S2. 151. F.2d 517 (3d Cir. 1945). See also Avco Mfg. Corp., 25 T.C. 975, 977-81 (1956).

83. INT. REv. Cone of 1954, § 355(a) (1) (A).

To escape the taint of a taxable acquisition of control, see note 32 supra, the distributing corporation could effect the required ownership through a nontaxable recapitalization under $\$ 368$ (a) (1) (E). Rev. Rul. 117, 1956-1 Cus. Bulx. 180.

84. See note 42 supra.

85. 238 F.2d 670 (1st Cir. 1956).

86. See notes $\$ 0,81$ supra and accompanying text. 
tators have challenged the desirability of section 355 's restrictions. ${ }^{87}$ Although the step-transaction rule has limited applicability, the device doctrines in fact constitute an important safeguard in the qualification of corporate divisions. Their availability does not, however, suggest the abolition of statutory restrictions. Rather, the combination of judicial and statutory requirements permits needed flexibility in this area of tax law.

The difficulties attending implementation of section 355's nonrecognition policy stem more from the regulations and practices of the Internal Revenue Service than from the language of the statute. Percentage definitions of five year business assets represent the most flagrant example. Only through gearing the determination of active business to the nature rather than extent of business assets can the purpose of section 355 be effectuated. Predictions of tax avoidance motivation not based on detailed analysis of all assets held by the corporate parties can have no greater foundation than mere speculation. The existing treatment of the active business requirement also errs in fostering a mechanical distinction between horizontally and vertically integrated businesses. While a practical distinction between public and close corporations might be valuable in administering the distribution of control restriction, a verticalhorizontal dichotomy overlooks economic reality in the active business context. Finally, the ninety per cent attribution rule of the 1939 Code should be relaxed under section 355 . The need for introducing these reforms is heightened by the pragmatic finality of the Commissioner's rulings on divisive reorganizations.

87. Lyons, Some Problems in Corporate Separations Under the 1954 Code, 12 TAx L. Rev. 15, 31-32 (1956); Committee on Taxation of the Bar of the City of New York, Bar Association Explains Weak Spots in Corporate Sections of 1954 Code, 2 J. TAXarron 322, 331 (1955). 